\title{
The Invisible Civil Servant: How Female Senior Lecturers in Sweden Narrate Work'
}

\section{Erika Wall ${ }^{2}$}

Associate Professor, Mid Sweden University, Sweden

\begin{abstract}
This article examines the public administration role of university personnel who are state employees by analyzing female senior lecturers' stories on working in Swedish universities, especially regarding how their role as a civil servant is narrated as part of their work. A performative narrative approach was used to analyze the in-depth interviews of four female senior lecturers at Swedish universities. Through the analysis, three shared storylines emerged: I don't think of myself as a civil servant; You have to keep a certain level and It's a solitary duty. The study revealed how the senior lecturer position was narrated by the interviewees in terms of duties to students and the public and the lack of efficient social support and knowledge. The findings are discussed as gendered expressions of working as a female senior lecturer in Sweden.
\end{abstract}

\section{KEYWORDS}

Civil servant / gender / narrative analysis / public administration / senior lecturer

\section{Introduction}

weden has a population of approximately 10 million people, including about 250,000 state employees. The academic sector of Sweden-the focus of this paper-is relatively large, and every fourth individual working at a university or college is a state employee (about 75,000; Statistics Sweden 2016). In terms of public administration, the universities of the Nordic countries are of special interest because it has been argued that they have been politicized to meet societal needs (Neave 2006; Nybom 2006). In other words, education is related to the idea of the public good, that is, referring to democracy and openness (Marginson 2011). Even though there are many similarities between the academic milieus of the Nordic countries, when it comes to academic autonomy (Estermann et al. 2011), there are also differences. For example, the universities in Sweden have less organizational autonomy than the universities in the other Nordic countries (Estermann et al. 2011). Within universities in the Nordic countries, including Swedish universities, collegiate leadership and administrative organization are combined, and personnel have to organize conflicting work tasks related to various factors, such as students, society and the scientific community (Lynch \& Ivancheva 2015). This study relates to the working life of those employed within this specific context of academia in Sweden.

\footnotetext{
${ }^{1}$ You can find this text and its DOI at https://tidsskrift.dk/njwls/index.

${ }^{2}$ Corresponding author: Erika Wall, Department of Health Sciences, Mid Sweden University, 83125

Östersund, Sweden; E-mail: erika.wall@miun.se (ORCID: 0000-0003-1984-8063).
} 
Many studies have examined what it means to work within various academic contexts-including academic careers (Archer 2008; Carvalho \& Santiago 2010; Lapping 2006; Morley 2005), management and leadership (Bolman \& Gallos 2011; Fullan \& Scott 2009; Kligyte \& Barrie 2014; Stensaker et al. 2012)—and how academics have managed recent changes within academia related to neoliberalism and new public management (Chandler et al. 2002; Czarniawska \& Genell 2002; Deem et al. 2007; Salter \& Tapper 2000). Despite this breadth of literature, personal stories on handling various aspects of working as university lecturers (Chandler et al. 2002; Czarniawska \& Genell 2002; Deem et al. 2007; Salter \& Tapper 2000) and structural discussions on higher education (Marginson 2011; Neave 2006; Nybom 2006), there is little research, regarding how university personnel balance their role as state employees serving the public good (cf. Marginson 2011) with their role as academics.

Previous research has shown that recent changes to academic work (Chandler et al. 2002; Czarniawska \& Genell 2002; Deem et al. 2007; Salter \& Tapper 2000) have impacted gender equity within academia (Acker \& Wagner 2017; Davies 2006; Harris et al. 2019; Morley 2011). For example, the higher demands of administrative tasks seem to affect women disproportionately (Brooks \& MacKinnon 2001; Davies 2006; Leonard 2001; Mama 2003; Wilson et al. 2010). Even though the increase in participation of women in academia, extensive research has shown that unequal conditions remain partly hidden within policies and informal power structures of academia (Morley 2011); thus, the often gendered outcomes of procedures for selection and promotions within academia is understood as neutral due to the hegemonic assumption that academia is rational and neutral in its functioning (Mama 2003).

Responding to this gap in the literature, this paper focuses on the complex position of female senior lecturers as public administrators, contributing valuable information to those interested, from a gender perspective, in the working life of those within academia. The present study also offers insights about various aspects of public administration and the role of senior lecturers, based on an analysis of narratives from women employed at colleges and universities in Sweden.

The aim of this study is to analyze female senior lecturers' stories of working in Swedish universities, especially in regard to how they view their role as a civil servant.

\section{Background and approach}

Senior lecturers teach and often conduct research; at the same time, they serve as public administrators. In other words, as defined by Lipsky (2010), senior lecturers are streetlevel bureaucrats, a concept used to describe public administrators who have direct contact with citizens and therefore act as a link between governmental work and the citizenry. Due to the distance between policy makers and street-level bureaucrats, Lipsky (2010) believes that policies are not only implemented but also framed in the everyday work of street-level bureaucrats. Thus, policies are reframed in relation to a given origin due to the civil servants' relatively high degree of discretion and organizational autonomy (Lipsky 2010).

Senior lecturers within academia are a particularly interesting group of street-level bureaucrats since public administration is not the core element of academic work. Instead, such tasks are embedded among other duties (Becher \& Trowler 2001; Cuthbert 1996). 
Moreover, within academia, organizational character and work tasks are complex, and academic work is distinctly divided into smaller parts, such as research, education and administration (Archer 2008; Becher \& Trowler 2001; Blaxter et al. 1998; Cuthbert 1996). Frequently, there are also employment-related insecurities within academia, such as temporary employment and the struggle to obtain research funding while simultaneously addressing students' needs. This situation is difficult to manage: 'Most academics are now contractually required to teach, research, engage with the public and be impactful. However, most academics are simultaneously unclear as to how to equally manage and fulfil each of these obligations' (Watermeyer 2016, p. 2272). In general, public organizations are seen as complex milieus due to conflicting tasks and responsibilities (Carpenter \& Krause 2012; Henkel 2005; Rainey \& Chun 2005). Universities can be understood as public organizations, and, at the same time, academic freedom frames academic work (Hamlyn 1996; Henkel 2005; Lynch \& Ivancheva 2015), making the situation even more complex.

Moreover, in academia, there are strong gender structures (Acker 2005, 2006; Angervall et al. 2018; Berger et al. 2015; Lipton 2017). Although overrepresented among students, women seldom become professors, and even though an almost equal number of men and women obtain PhDs in Sweden, only 22\% of professors in 2011 were women (Statistics Sweden 2012). Furthermore, women in academia report that they receive less support from institutions and peers and find themselves in careers that do not lead to senior positions (Morley 2014); instead, they typically receive contracts focused on teaching and/or administration (Carvalho \& Santiago 2010) and informal work, such as serving on institutional committees and taking care of the 'academic family' (Guarino \& Borden 2017, p. 690). Research on women in academia shows how their careers are hindered by informal structures of gender inequality hidden behind formal equality between women and men (Frank Fox et al. 2017; Husu 2005; Mama 2003; Morley 2011). Moreover, the gendered structure of academia is intertwined with gender structures in other parts of life. For example, even though female participation in the labor market in most countries has increased (Aliaga 2006), women's total workload, including not only paid work but also unpaid work at home, exceeds that of men (MacDonald et al. 2005; Väänänen et al. 2004).

Returning to the gendered patterns in working life in academia, several governmental investigations have been made on the differences between men and women, and there is an ongoing discussion due to gender equality (Keisu et al. 2015). That is, work on gender equality within universities is intertwined with the ongoing process of transformation and marketization of academia (Lynch \& Ivancheva 2015; Watermeyer 2016), and most of the responsibility for gender equality has been transferred to universities (Keisu et al. 2015). To sum up, the gendered structure of academia partly depends on the changing structure of academic work itself, in which competition between individuals, as well as organizations, defines success (Müller \& Kenney 2014).

Furthermore, work experiences within universities are framed by the specific academic organization. In Sweden, universities have a 'special status in terms of autonomy and academic freedom' (Enders et al. 2013, p. 7), which means the context is defined by individualizing practices (Gill 2009). Previous studies on how personnel deal with complexity within academia have illustrated how academics are caught between two conflicting systems of managerial organization and academic organization (Henkel 2005, cf. Clegg 2008; Shams 2019; Whitchurch 2008). Meanwhile, academia is also part of 
the ongoing societal process of transformation, incorporating models of management (Lynch \& Ivancheva 2015; Watermeyer 2016) in a societal process where the term public sector itself has been challenged (Newman \& Clarke 2009); thus, the boundaries between various parts of society, such as the state, the market and civil society, are increasingly vague (Kamp et al. 2013). Specifically, regarding academia, there is a strong consensus among scholars that there has been an increased adoption of managerialism in recent years (Clarke \& Knights 2015; Shams 2019; Sparkes 2007), which has been described as a 'bureaucratic revolution in universities' (Nash 2019, p. 178). However, as argued by Nash (2019), it is important to distinguish between marketizing and bureaucracy in terms of guaranteeing the value of education. That is, the neoliberal idea of bureaucracy focusing on value for money should be understood as existing side by side with the idea of bureaucracy supporting education and the public good (cf. Marginson 2011). The latter is oriented towards equal treatment of students, formalizing courses and assessments and further formalizing communication between the university and the student (Nash 2019). Formal and informal leadership both play important roles in power relations within academia (Gill 2009; Gillies \& Lucey 2007; Jarvis 2000; Stigmar 2008).

Against this background, the present study explores the working lives of female senior lecturers, especially how public administration is viewed as part of their work. Here, gender is understood as socially constructed, and, by that, academia is selfevidently understood as gendered (cf. Haslanger 2012). That is, not only do individuals perform gender (doing gender) but so do organizations (Morley 1999). As shown above, within academia, gender hierarchies are evident (Weiler 2008), intertwined with the complexity of academic work (Thornton 2013).

\section{Methods}

This study uses a narrative method inspired by a performative approach (Peterson $\&$ Langellier 2006), which has previously been used in feminist studies (see, e.g., Czarniawska 2004; Morison \& Macleod 2013). This approach was chosen to frame everyday perspectives on academic work wherein the story told by the interviewee provides the possibility to integrate their subjective experience into the specific context of others. The stories told give information not only about specific events and how they are viewed but also about the storyteller herself, who is understood as an active agent (Elliot 2005; Sfard \& Prusak 2005). The performative perspective of narrative analysis describes narrative as both making - creating a product side by side with other products (e.g., texts, images)—and doing-positioning the storyteller throughout the story (Peterson \& Langellier 2006). Furthermore, the performative narrative approach is especially useful when analyzing gendered experiences. The performative approach to narrative analysis is built upon Butler's (1990) perspectives of how gender is (re)produced by repetitions of doings, in which every repetition is slightly different. By telling stories, the storyteller claims the right to define what happened and gives his/her subjective perspective on what happened (i.e., how the story should be narrated). Thus, storytelling can be described as an expression of how individuals make sense of a situation (Ericsson \& Rakar 2017). Positioning is important in this perspective; the storyteller functions as a character in his/her own story, taking various positions in different contexts and making

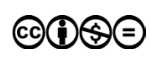


the story an act of performance (Peterson \& Langellier 2006). Accordingly, the narrative itself reproduces existing power relations, which means that the narrative analysis can reveal social constructions. Regarding stories of working life, scholars acknowledge the importance of narrative analysis, especially in regard to its possibilities for revealing social relations (Brown 1985; Currie et al. 2009).

In the present study, in-depth interviews were used to gather narratives on the everyday experiences of various aspects of working in academia. Interviews were preferred to uncover personal stories about working as senior lecturers at universities. In relation to the chosen performative narrative approach, involving detailed analysis of text segments (transcripts) to reveal common stories of subjective experiences, the ambition was to focus on the depth of a few very in-depth interviews versus the breadth of many more superficial ones. Specifically, the material analyzed in this article was gathered from interviews with four interviewees. After these interviews were done, it was found in the analysis process that the collected data revealed insightful information on the research question. That is, the storylines provided sufficient insights to answer the aims of the study (cf. Charmaz 2006).

To preserve the participants' confidentiality, the interviewees were renamed using four of the most common names of women living in Sweden: Anna, Eva, Maria and Karin. All of the women were employed as senior lecturers at four different Swedish universities and university colleges (hereafter referred to as universities) for less than five years; all of them worked in humanities faculties but in different subject areas. They reported similar tasks and duties regardless of whether they were employed at a university or a university college.

The interviewees were recruited through informal contacts; none of them knew the researcher personally or were recruited from the researcher's workplace. Each interview began with some small talk to make introductions between the interviewee and the researcher. Next, the researcher ensured that the interviewee had read the information letter, which was sent before the interview. The letter included the following information: the project aim; Mid Sweden University and the researcher's responsibility for the study; details on the data collection process, including the in-depth interviews, their subsequent literal transcription and the removal of recognizable names of persons, universities, cities, etc., from the research notes to preserve confidentiality; details on how the data would be analyzed and communicated to the research community and the public; a statement that the project was not covered by the research ethics regulation in Sweden and had, therefore, not undergone an ethics review; and the fully voluntary nature of participation in the study, including the interviewee's right to end the interview at any point without explanation.

The researcher summarized the information from the letter, which was designed based on research ethics regulations formulated by the Swedish Research Council, before the interview started to ensure that the interviewees understood the study conditions. After the introductory information was provided and the interviewee gave formal consent to participate in the study, the interview began. The interview, based on a thematic interview guide, focused on issues related to the interviewee's position as a senior lecturer and their role as a civil servant. In addition, personal questions collected background information on their family situation, career and current position.

The researcher analyzed the data through several readings of the material, at first to understand the information in full and later to find shared storylines. The initial step 
of the analysis process was reducing the material by making case narratives (Sfard $\&$ Prusak 2005). Specific parts of the transcripts were coded and sorted to highlight specific events and situations, the passage of time and relationships between the storyteller and others (McAlpine 2016). The researcher assigned certain codes to specific lines from the transcripts, which were continually compared to each other to find similarities, as well as differences, between the four personal narratives. Throughout this process, categorizations and demarcations were made and remade (cf. Keady et al. 2009). Consequently, central perspectives on working in academia were found throughout the empirical material. Together, these formed shared narrative storylines (Gergen 1988; Keady et al. 2009) that aimed to explain how the interviewees commonly narrated the position of senior lecturer. From a narrative point of view, the researcher interpreted the women's stories as expressions of their experiences and as a doing in itself. In other words, the researcher understood the retelling experiences as a performative act, wherein social relations were revealed (Peterson \& Langellier 2006).

\section{Results}

In this section, the results of the narrative analysis are presented. The female senior lecturers' stories were analyzed in terms of how they narrated their role as civil servants as part of their work. Even though the stories were distinctly linked to the interviewees' subjective experiences and circumstances of being women working as senior lecturers, three common storylines were found: 1) I don't think of myself as a civil servant, 2) You have to keep a certain level and 3) It's a solitary duty. The three storylines are equally relevant in terms of describing the material. Due to the characteristics of the storylines, they are presented in the order to which they relate to the aim of the study. The first storyline offers information on the context, including how empirically defined roles embedded in their work were narrated. The second highlights handling work tasks related to public administration, and the third concerns making sense of work through a common story of doing work singlehandedly.

Together, the shared storylines provide information on how the participants narrated their working life in academia and the various roles they expressed as part of the senior lecturer position, especially their role as a civil servant. However, one must bear in mind that the shared storylines describe the experiences of these specific women. Thus, the stories told in the interviews are clearly subjective and reflect not only the participants' views on working as senior lecturers, but also the active positioning of the presenter through the story (cf. Peterson \& Langellier 2006). From this, more and/or other storylines would be found if interviewing more and/or other participants.

\section{I don't think of myself as a civil servant}

The first storyline illuminates the uncertainties of the interviewees in defining the senior lecturer position and unveils how the position was narrated in terms of the various roles embedded within it. When asked about being a senior lecturer, the interviewees narrated the position in general terms, suggesting it was difficult for them to define the position. Instead, several roles emerged as embedded within the position. The most central ones 
were being a lecturer and researcher. Their role as a lecturer was narrated as consisting of duties such as teaching in the classroom and/or online, answering e-mails from students, meeting with students and colleagues and supervising theses at the $\mathrm{PhD}$ candidate, master's and/or candidate's level. However, the descriptions that emerged from the interviewees' stories of this role also included different kinds of tasks, such as handling 'difficult students' (Anna) and trying to reorganize the structure of specific courses. Their role as a researcher was narrated as opposite the role as a lecturer. This role was expressed as the preferred one and associated with high status. However, the participants found it difficult to prioritize time for research, even when such time was designated in the position's duties. An administrative role also emerged in the material. Some of the mentioned administrative tasks were part of their role as a lecturer (e.g., reporting ratings), but most were not specifically narrated as related to education or research. Examples included planning vacations, handling travel bills and being responsible for a research group (as mentioned by one of the interviewees).

Notably, when sorting out the complexity of the senior lecturer position, the analysis showed that none of the interviewees spontaneously narrated public administration or their role as a civil servant. In fact, when the interviewees were asked about public administration issues, such as universities being financed by taxes, general perspectives emerged, as in the following example:

You get a little tricked by the university environment; we don't talk much about whether we are financed by public funds-you do that [being financed by taxes] regardless of whether you teach or research. For the most part, it's also tax money; it's not 'our' money-it's the public's money. We have received our education from the public; we are financed by the public; we make our careers on our tax money. We do not talk about it, not even in relation to publishing research behind pay walls and not in relation to the responsibility we have to spend this money. (Karin)

Thus, universities as public institutions were highlighted, but the specific senior lecturer position was not directly narrated in relation to the characteristics of governmental employment.

To understand how these female senior lecturers narrated their complex position, the interviewees were asked specific questions about how they expressed their role as part of public administration. However, none of the interviewees spontaneously narrated public administration or their role as a civil servant as part of their senior lecturer position:

It does not feel like working as an authority. Or how it is to be a state employee in any way. Obviously, it is problematic. An autonomous university, to think freely, and all that. You are an authority, but you do not implement government policy. While other authorities have it as [their] mission, this is in more of an independent manner. (Eva)

Interestingly, the analysis clearly showed that the interviewees narrated their role as a civil servant as almost invisible to themselves. Or, as Eva put it when explicitly asked about her thoughts on being a civil servant: 'I would never think of myself as a civil servant!' 


\section{You have to keep a certain level}

The second shared storyline displays how various duties were narrated as associated with their role as a civil servant by the interviewees. Specifically, the role as civil servant seemed to be narrated in terms of responsibilities regarding relationships to the students and the public. Also, the public, especially as taxpayers, was central to how the interviewees narrated the senior lecturer position:

I have a responsibility towards taxpayers who pay my salary. [I] try to be fair, open. In fact, it's [work], not something I do for my own sake. There is someone else who stands for the bullets [money] and is entitled to get rid of it. This relates to teaching as well as research. Almost more so [to] research. (Anna)

Therefore, the interviewees understood the senior lecturer position in relation to public financing and societal values and responsibilities. According to Karin, public good is about having a position where you are involved in maintaining important values in society and [you need] to be aware that you are paid by public funds'.

Questions specifically related to public administration issues triggered further meaning-making of this aspect of the interviewees' work. Pointing out the civil servant role embedded in the senior lecturer position activated stories on responsibilities. As a result, the interviewees' indicated that the role as a civil servant meant being responsible, and those responsibilities were linked to specific aspects of their work and addressed to specific recipients:

[I focus on] trying to remember the overall principles [and] what my role really is. That it is really a very good job, an important job. In particular, I try to maintain it in relation to students. When I can feel my irritability increase and I lose my empathy, I try to remember] that I am here for their sake and not the other way around. (Karin)

The narrations of the role as a civil servant illuminated the interviewees' positioning in academia, showing the importance of the position the interviewees had taken and who they were in relation to. That is, in the material, the relationship between the senior lecturer and the student emerged as most central in the discussion about their role as a civil servant, as can be seen in the quotation below:

Everything I say and do to them [my students] has the potential to affect their performance when they are examined, which is really scary. It is a great responsibility. That's part of it. Now I grade exams. And it is not I who held the course, and it is not I who designed the exam. I [am] only [the] examine[r]. Therefore, it may become even more clear that it [work/grading] is an exercise of authority. (Karin)

Hence, what appears most relevant in the material are the interviewees' responsibilities regarding students and education, as seen in the following statements from Anna, Eva and Maria on the importance of good education:

We are going to give good education, this is the basic thing we must do, and we should also be required to maintain a certain level of education, and I feel that I do not really 
get the support to do it. I think it's most important in relation to education, it's a really important job. (Anna)

I think that the most important thing is the exercise of authority in contact with the students ..., in education. It is an important assignment when I meet students. On the one hand, it must be [a] legal requirement. On the other [hand], it is my mission that the students meet the requirements. (Eva)

As an examiner, I often do [reflect on the role as a civil servant]. When you sit with 120 students, and everyone has not performed very well. It is important to remember that it is the exercise of authority; they must meet the requirements in order to be approved. To be able to meet high demands and not to slip into it. To be consistent with the requirements. We agree like that, I feel that. (Maria)

\section{It's a solitary duty}

The last storyline expresses how the senior lecturer position is commonly narrated as a single-handed assignment or a solitary duty. In fact, the individual perspectives on the various work tasks and multiple roles embedded in the senior lecturer position (lecturer, researcher, administrator and civil servant) were notable. The interviewees did not talk about senior lecturers from a collective perspective or in terms of what the position means in general. Instead, they expressed experiences from their own individual situations.

The interviewees' reasoning about their role as a civil servant further illuminated their individual perspectives on the senior lecturer position. When discussing public administration issues, thoughts about being individually privileged seemed to be awakened. For example, when Anna talked about responsibilities as a civil servant in relation to a collective (i.e., students), individual privileges were intertwined in the narration: 'As I see it, it's such an incredible advantage to get paid to have fun! Compared to people who get paid to do boring things. I have had such a trip!'

Similarly, the interviewees narrated the work tasks embedded in the various roles as researcher, teacher and/or civil servant not only from an individual perspective but also in relation to being lonesome and unaided. The interviewees' narratives about work were built upon expectations of handling the complex position single-handedly, as Eva illustrated: 'You are expected to force yourself. You can always do even better. You can always accomplish even more'.

In addition, Anna remembered that 'a lot of such things', that is, issues on public administration, had come up during orientation day as a new $\mathrm{PhD}$ student about eight years previously. However, some duties associated with public administration were well known: 'Yes, maybe, about grading. It should be done within a certain time' (Eva). Despite that clarity, the interviewees perceived responsibilities in the role as a civil servant as invisible within the organization. From the interviews, knowledge about individual duties in the role as a civil servant seemed to relate to individual interest and background. For example, Eva stated that she had read civil law: 'So from that, I have basic understanding of administrative law and labor law'. One of the interviewees explicitly stated that further knowledge on public administration would be appreciated: 
I would love to get more information [on public administration]; it would be amazing! Knowing, getting it together, so you do not need-in relation to individual students, individual cases. Getting a combined education would be great. (Maria)

\section{Discussion}

This study explored how women working at universities in Sweden narrate their position as a senior lecturer, specifically their role as a civil servant, by analyzing how four interviewees narrated their work experiences.

The three shared storylines that emerged in the analysis illuminated how the interviewees described several roles embedded in the senior lecturer position. Furthermore, the storylines expressed somewhat contradictory perspectives regarding their role as a civil servant. On the one hand, this role was narrated as almost invisible; on the other hand, the interviewees expressed various responsibilities regarding quality in education and examinations, which can be understood in terms of public administration. However, similar to previous research, the role conflict between being a lecturer and being a researcher was highlighted within the material; at the same time, the senior lecturer position was described as including an administrative role (cf. Archer 2008; Becher \& Trowler 2001; Blaxter et al. 1998; Cuthbert 1996; Watermeyer 2016).

In relation to the storylines that emerged from these subjective narratives, the idea of universities as part of the public administration system is especially interesting since a picture emerged of a clearly individualistic culture in which public administration and the role of civil servant were almost invisible. According to Lipsky (2010), street-level bureaucrats are recognized by their everyday relationship to the public. In light of this, it is remarkable that none of the interviewees emphasized their role as a civil servant as an essential part of their work. Also, it is interesting that none of the interviewees recalled that they received any education to prepare them for their role as a state official with responsibilities related to overseeing and, for example, grading students.

The present analysis illuminates subjective thoughts and experiences regarding the role of civil servant. Due to uncertainties regarding this role, it was narrated in relation to various relationships, while the storylines found in the narration expressed duties that lacked sufficient support. Pointing out the importance of 'keep[ing] a certain level of education' (Anna) and maintaining 'authority in contact with the students' (Eva) confirmed the position of senior lecturer as a street-level bureaucrat, as described by Lipsky (2010). However, the invisibility of the role of civil servant can be seen as something else, that is, a position in academia that is not typically described as a street-level bureaucrat. Instead, the invisibility of the role relates to the growing literature regarding the structural changes in higher education, which points out that universities are more and more understood as businesses with consumers (i.e., students; Clarke \& Knights 2015; Gill 2009; Nash 2019). Based on the literature on the ongoing process of transformation and the incorporation of management models into academia (Lynch \& Ivancheva 2015; Watermeyer 2016), the identified storylines may be understood in relation to an academic milieu in which duties must be managed by the individual herself. Therefore, consideration should be given to whether the common stories, here presented as storylines, of how to manage work on one's own are a result of a broader ongoing process of individualization and the transformation of academia. 
Despite the interrelation between experiences of the various roles embedded in the senior lecturer position and the marketization and individualization context characterizing academia, the storylines in this paper should be understood as gendered experiences (Angervall et al. 2018; Berger et al. 2015; Carvalho \& Santiago 2010; Lipton 2017). It is reasonable that the experience of the role of civil servant is interwoven with gendered experiences of being a woman working as a senior lecturer (cf. Acker \& Wagner 2017; Davies 2006; Harris et al. 2019; Morley 2011, 2016). As such, the storylines expressing the expectation of singlehandedly (It's a solitary duty) providing high-quality education (You have to keep a certain level) should be analyzed from a gender perspective. In fact, these results might be a reflection of the gendered structures of academia in which women are affected by higher demands of administrative tasks (Brooks \& MacKinnon 2001; Davies 2006; Leonard 2001; Mama 2003; Wilson et al. 2010) and are expected to focus on teaching and/or administration (Carvalho \& Santiago 2010; Guarino \& Borden 2017), where female senior lecturers manage everyday duties related to other people, sometimes defined as institutional housekeeping, to a higher extent than men (Bird et al. 2004; Guarino \& Borden 2017).

This narrative study of a few women working as senior lecturers in Sweden shows how the public-administration aspects of work were made almost invisible in the narrations of working life. However, when explicitly focusing on these aspects, they were narrated as important for the benefit of students and as activities performed singlehandedly. When discussing these results from a gender perspective, they became fuzzier. The storylines on keeping a certain level and the experiences of handling work tasks alone could apply to narrations of the female experience of working in academia, wherein unequal conditions between women and men are hidden by policies and procedures understood as gender-neutral (Mama 2003; Morley 2011), rather than relating to the public administration context. That is, the results can be related to previous research showing women taking a greater responsibility for relationships within academia (Guarino \& Borden 2017) found to be intertwined with processes and structures that are gendered, creating unequal conditions between women and men (Brooks \& MacKinnon 2001; Davies 2006; Leonard 2001; Morley 2011; Wilson et al. 2010). Overall, the interconnections between various work tasks and the gendered structure of academia should be further investigated, along with how public administration is handled and related to sensemaking by women and men working as senior lecturers.

The implications from this study should not be overemphasized. The analysis and discussion within this paper are based upon a small amount of data and should, therefore, be considered an initial effort to highlight how women working as senior lecturers experience their role as a civil servant. The narrative approach was chosen due to the insights possible to reach by analyzing stories of interviewees, and, by that, capturing the subjectivity within the creation and positioning of narratives (cf. Peterson \& Langellier 2006). Although narrative analysis makes it possible to delve deeply into less extensive material, the foundational material for analyses in the present study was narrow, limiting its external validity (generalizability) because the narrated stories are exclusive to the interviewees. Furthermore, to conduct the narrative analysis, subjective storytelling was employed even though other data collection and analysis methods could have been used. For example, it would have been interesting to investigate sense-making and social constructs related to public administration and the role of civil servant through a focus group study, and this approach could be used in future studies. Choosing focus 
group interviews would strengthen the possibility of comparing various perspectives (Morgan 1996). Analysis based on material collected by focus group interviews could give information not only about the subjective story of each participant but on the social construction of norms (Mechlenborg Kristiansen \& Grønkjær 2018), in this case, of working as a senior lecturer. Also, ethnographical methods based on observations could be an alternative when it comes to revealing everyday work life as a senior lecturer, previously shown by Pereira (2017), who explore gendered processes of academic valuation, drawing on data collected within academic work.

\section{Conclusion}

Although a large number of Swedish state employees work in universities, senior lecturer roles are seldom studied in terms of their role in public administration. To help fill this gap, this paper presented information on how the embedded roles of the senior lecturer position are narrated, especially the role of civil servant. Specifically, this study revealed how the senior lecturer position was narrated by four interviewees in terms of duties to the public and students, albeit without effective social support and a lack of knowledge on the individual's role within public administration. Insights were also offered for how these narratives could be understood as expressions of the gendered experiences of woman working as senior lecturers in Sweden.

Using a performative narrative approach, the study examined how the senior lecturer position is narrated from an individualistic perspective and how the role of civil servant was made almost invisible by the interviewees. Furthermore, there seemed to be a contradiction between the complexity of the senior lecturer position and the common ideas of street-level bureaucracy, which may relate to the process of transformation within academia. Since models of management are being incorporated into academia as part of this transformation, there is a need for further studies on the working life of senior lecturers within Nordic countries from a public administration perspective.

Finally, despite the non-generalizability the findings of this small study based on the subjective experiences of a few female senior lecturers, the present study illuminates the importance of placing further emphasis on public administration in academia, especially regarding senior lecturers' role as civil servants and the interconnections between gender structures and how various work tasks are handled, as well as related sense-making efforts.

\section{Disclosure statement}

The author reports no potential conflict of interest. This research received no grant from any funding agency within the public, commercial or not-for-profit sectors.

\section{References}

Acker, J. (2005). Class Questions: Feminist Answers, Lanham: Rowman \& Littlefield.

Acker, J. (2006). Inequality regimes: gender, class and race in organizations, Gender \& Society 20(4): 441-464. doi: https://doi.org/10.1177/0891243206289499. 
Acker, S. \& Wagner, A. (2017). Feminist scholars working around the neoliberal university, Gender and Education 31(1): 62-81. doi: https://doi.org/10.1080/09540253.2017.12 96117.

Aliaga, C. (2006). How is the Time of Women and Men Distributed in Europe?, Eurostat. Available at: https://ec.europa.eu/eurostat/web/products-statistics-in-focus/-/KS-NK-06-004.

Angervall, P., Gustafsson, J. \& Silfver, E. (2018). Academic career: on institutions, social capital and gender, Higher Education Research \& Development 37(6): 1095-1108. doi: https://doi.org/10.1080/07294360.2018.1477743.

Archer, L. (2008). Younger academics' constructions of 'authenticity', 'success' and professional identity, Studies in Higher Education 33(4): 385-403. doi: https://doi.org/10.1080/ 03075070802211729.

Becher, T. \& Trowler, P. (2001). Academic Tribes and Territories, $2^{\text {nd }}$ edn., Maidenhead: Open University Press.

Berger, L., Benschop, Y. \& van den Brink, M. (2015). Practising gender when networking: the case of university-industry innovation projects, Gender, Work \& Organization, 22(6): $556-578$.

Bird, S., Litt, J. \& Wang, Y. (2004). Creating status of women reports: institutional housekeeping as 'women's work', NWSA Journal 16(1): 194-206. doi: https://oi.org/10.1353/ nwsa.2004.0027.

Blaxter, L., Hughes, C. \& Tight, M. (1998). Writing on academic careers, Studies in Higher Education 23(3): 281-295.

Bolman, L. G. \& Gallos, J. V. (2011). Reframing Academic Leadership, San Francisco: Jossey-Bass.

Brooks, A. \& MacKinnon, A. (eds.) (2001). Gender and the Restructured University, Buckingham: Open University Press and the Society for Research into Higher Education.

Brown, M. H. (1985). That reminds me of a story: speech action in organizational socialization, Western Journal of Communication 49(1): 27-42. doi: https://doi.org/10.1080/ 10570318509374179.

Butler, J. (1990). 'Performative acts and gender constitution: an essay in phenomenology and feminist theory', in Case, S. (ed.) Performing Feminisms: Feminist Critical Theory and Theatre, Baltimore: John Hopkins University Press, pp. 73-83.

Carpenter, D. P. \& Krause, G. A. (2012). Reputation and public administration, Public Administration Review 72(1): 26-32. doi: https://doi.org/10.1111/j.1540-6210.2011.02506.x.

Carvalho, T. \& Santiago, R. (2010). New challenges for women seeking an academic career: the hiring process in Portuguese higher education institutions, Journal of Higher Education Policy and Management 32(3): 239-249. doi: https://doi.org/10.1080/13600 801003743331.

Chandler, J., Barry, J. \& Clark, H. (2002). Stressing academe: the wear and tear of the new public management, Human Relations 55(9): 1051-1069. doi: https://doi.org/10.1177/0 0187267020550090019.

Charmanz, K. (2006). Constructing Grounded Theory: A Practical Guide through Qualitative Analysis, Thousand Oaks: SAGE.

Clarke, C. A. \& Knights, D. (2015). Careering through academia: securing identities or engaging ethical subjectivities? Human Relations 68(12): 1865-1888. doi: https://doi. org/10.1177\%2F0018726715570978.

Clegg, S. (2008). Academic identities under threat?, British Educational Research Journal 34(3): 329-345. doi: https://doi.org/10.1080/01411920701532269.

Currie, G., Humpreys, M., Waring, J. \& Rowley, E. (2009). Narratives of professional regulation and patient safety: the case of medical devices in anaesthetics, Health, Risk \& Society 11(2): 117-136. doi: https://doi.org/10.1080/13698570902784257.

Cuthbert, R. (ed.) (1996). Working in Higher Education, Maidenhead: Open University Press. 
Czarniawska, B. (2004). Narratives in Social Science Research, London: SAGE.

Czarniawska, B. \& Genell, K. (2002). Gone shopping? universities on their way to the market, Scandinavian Journal of Management 18(4): 455-474. doi: https://doi.org/10.1016/ S0956-5221(01)00029-X.

Davies, B. (2006). Women and transgression in the halls of academe, Studies in Higher Education 31(4): 497-509. doi: https://doi.org/10.1080/03075070600800699.

Deem, R., Hillyard, S. \& Reed, M. (2007). Knowledge, Higher Education, and The New Managerialism: The Challenging Management of UK Universities, Oxford: Oxford University Press.

Elliot, J. (2005). Using Narrative in Social Research: Qualitative and Quantitative Approaches, London: SAGE.

Enders, J., De Boer, H. \& Weyer, E. (2013). Regulatory autonomy and performance: the reform of higher education revisited, Higher Education 65(1): 5-23. doi: https://doi. org/10.1007/s10734-012-9578-4.

Ericsson, U. \& Rakar, F. (2017). Med minnen av en framtid: integration och etablering som meningsskapande processer [With memories of a future: integration and establishment as meaning-making processes], Arbetsmarknad \& Arbetsliv [Labour Market \& Working Life] 23(1): 10-26.

Estermann, T., Nokkala, T. \& Steinel, M. (2011). University Autonomy in Europe II: The Scorecard, Brussels: European University Association.

Frank Fox, M., Bunker Whittington, K. \& Linková, M. (2017). 'Gender, (in)equity, and the scientific workforce’, in Felt, U., Fouché, R., Miller, A. \& Smith-Doerr, L. (eds.) Handbook of Science and Technology Studies, Cambridge: MIT Press, pp. 701-733.

Fullan, M. \& Scott, G. (2009). Turnaround Leadership for Higher Education, San Francisco: Jossey-Bass.

Gergen, M. M. (1988). 'Narrative structures in social explanation', in Antaki, C. (ed.) Analysing Everyday Experience: A Casebook of Methods, London: SAGE, pp. 94-112.

Gill, R. (2009). Breaking the silence: the hidden injuries of neo-liberal academia, secrecy and silence in the research process, Feministische Studies 34(1): 39-55. doi: https://doi. org/10.1515/fs-2016-0105.

Gillies, V. \& Lucey, H. (eds.) (2007). Power, Knowledge and the Academy: The Institutional is Political, Basingtoke: Palgrave Macmillan.

Guarino, C. M. \& Borden, V. M. H. (2017). Faculty service loads and gender: are women taking care of the academic family?, Research in Higher Education 58(6): 672-694. doi: https://doi.org/10.1007/s11162-017-9454-2.

Hamlyn, D. W. (1996). The concept of a university, Philosophy 71(276): 205-218. doi: https://doi.org/10.1017/S0031819100041449P.

Harris, C., Myers, B. \& Ravenswood, K. (2019). Academic careers and parenting: identity performance and surveillance, Studies in Higher Education 44(4): 708-718. doi: https:// doi.org/10.1080/03075079.2017.1396584.

Haslanger, S. (2012). Gender and race: (what) are they? (what) do we want them to be?, Nous 34(1): 31-55.

Henkel, M. (2005). Academic identity and autonomy in a changing policy environment, Higher Education 49(1): 155-176. doi: https://doi.org/10.1007/s10734-004-2919-1.

Husu, L. (2005). 'Women's work-related and family-related discrimination and support in academia', in Texler Segal, M. \& Demos, V. (eds.) Gender Realities: Local and Global, Bingley: Emerald Group, pp. 161-199.

Jarvis, P. (2000). The changing university: meeting a need and needing to change, Higher Education Quarterly 54(1): 43-67. doi: https://doi.org/10.1111/1468-2273.00144.

Kamp, A., Klemsdal, L. \& Gonäs, L. (2013). Working in the public sector: introduction to the thematic issue, Nordic Journal of Working Life Studies 3(2): 1-8. 
Keady, J., Clarke, C. L., Wilkinson, H., Gibb, C. E., Williams, L., Luce, A. \& Cook, A. (2009). Alcohol-related brain damage: narrative storylines and risk constructions, Health, Risk \& Society 11(4): 321-340. doi: https://doi.org/10.1080/13698570903015743.

Keisu, B., Abrahamsson, L. \& Rönnblom, M. (2015). Entrepreneurship and gender equality in academia: a complex combination in practice, Nordic Journal of Working Life Studies 5(1): 69-92.

Kligyte, G. \& Barrie, S. (2014). Collegiality: leading us into fantasy: the paradoxical resilience of collegiality in academic leadership, Higher Education Research \& Development 33(1): 157-169. doi: https://doi.org/10.1080/07294360.2013.864613.

Lapping, C. (2006). Recodifications of academic positions and reiterations of desire: change but continuity in gendered subjectivities, Studies in Higher Education 31(4): 423-437. doi: https://doi.org/10.1080/03075070600800509.

Leonard, D. (2001). A Woman's Guide to Doctoral Studies, Buckingham: Open University Press.

Lipsky, M. (2010). Street-level Bureaucracy: Dilemmas of the Individual in Public Service, London: SAGE.

Lipton, B. (2017). Measures of success: cruel optimism and the paradox of academic women's participation in Australian higher education, Higher Education Research \& Development 36(3): 486-497. doi: https://doi.org/10.1080/07294360.2017.1290053.

Lynch, K. \& Ivancheva, M. (2015). Academic freedom and the commercialisation of universities: a critical ethical analysis, Ethics in Science and Environmental Politics 15(1): 71-85. doi: https://doi.org/10.3354/esep00160.

MacDonald, M., Phipps, S. \& Lethbridge, L. (2005). Taking its toll: the influence of paid and unpaid work on women's well-being, Feminist Economics 11(1): 63-94.

Mama, A. (2003). Restore, Reform but do not Transform: The Gender Politics of Higher Education in Africa, Journal of Higher Education in Africa, 1(1): 101-125.

Marginson, S. (2011). Higher education and public good, Higher Education Quarterly 65(4): 411-433. doi: https://doi.org/10.1111/j.1468-2273.2011.00496.x.

McAlpine, L. (2016). Why might you use narrative methodology? a story about narrative, Eesti Haridusteaduste Ajakiri 4(1): 32-57. doi: https://doi.org/10.12697/eha.2016.4.1.02b.

Mechlenborg Kristiansen, T. \& Grønkjær, M. (2018). Focus groups as social arenas for the negotiation of normativity, International Journal of Qualitative Methods 17(1): 1-11. doi: https://doi.org/10.1177/1609406917747393.

Morgan, D. L. (1996). Focus groups, Annual Review of Sociology 22(1): 129-152. doi: https://doi.org/10.1146/annurev.soc.22.1.129.

Morison, T. \& Macleod, C. (2013). A performative-performance analytical approach: infusing Butlerian theory into the narrative-discursive method, Qualitative Inquiry 19(8): 566-577.

Morley, L. (1999), Organising feminisms, the micropolitics of the academy, New York, St. Martin's Press.

Morley, L. (2005). Opportunity or exploitation. women and quality assurance in higher education, Gender and Education 17(4): 411-429. doi: https://doi.org/10.1080/09540 250500145106.

Morley, L. (2011). Misogyny posing as measurement: disrupting the feminization crisis discourse, Contemporary Social Science: Journal of the Academy of Social Sciences 6(2): 223-235. doi: https://doi.org/10.1080/21582041.2011.580615.

Morley, L. (2014). Lost leaders: women in the global academy, Higher Education Research \& Development 33(1): 114-128. doi: https://doi.org/10.1080/07294360.2013.864611.

Morley, L. (2016). Troubling intra-actions: gender, neo-liberalism and research in the global academy, Journal of Education Policy 31(1): 28-45. doi: https://doi.org/10.1080/02680 939.2015.1062919. 
Müller, R. \& Kenney, M. (2014). Agential conversations: interviewing postdoctoral life scientists and the politics of mundane research practices, Science as Culture 23(4): 537-559. doi: https://doi.org/10.1080/09505431.2014.916670.

Nash, K. (2019). Neo-liberalisation, universities and the values of bureaucracy, The Sociological Review 67(1): 178-193. doi: https://doi.org/10.1177/0038026118754780.

Neave, G. (2006). 'On time and fragmentation: sundry observations on research, the university and politics from a waveringly historical perspective', in Blückert, K., Neave, G. \& Nybom, T. (eds.) The European Research University: An Historical Parenthesis?, New York: Palgrave Macmillan and International Association of Universities, pp. 63-76.

Newman, J. \& Clarke, J. (2009). Publics, Politics and Power: Remaking the Public of Public Services, London: SAGE.

Nybom, T. (2006). 'Creative intellectual destruction or destructive political creativity? critical reflections on the future of European "knowledge production"', in Blückert, K., Neave, G. \& Nybom, T. (eds.) The European Research University: An Historical Parenthesis?, New York: Palgrave Macmillan and International Association of Universities, pp. 3-16.

Pereira, M. D. M. (2017). Power, Knowledge and Feminist Scholarship. An Ethnography of Academia, New York: Routledge.

Peterson, E. E. \& Langellier, K. M. (2006). The performance turn in narrative studies, Narrative Inquiry 16(1): 173-180. doi: https://doi.org/10.1075/ni.16.1.22pet.

Rainey, H. G. \& Chun, Y. H. (2005). Public and private management compared, in Ferlie, E., Lynn, Jr., L. E., Pollitt, C. \& Lynn, L. E. (eds.) The Oxford Handbook of Public Management, Oxford: Oxford University Press.

Salter, B. \& Tapper, T. (2000). The politics of governance in higher education: the case of quality assurance, Political Studies 48(1): 66-87. doi: https://doi.org/10.1111/14679248.00251.

Sfard, A. \& Prusak, A. (2005). Telling identities: in search of an analytical tool for investigating learning as a culturally shaped activity, Educational Researcher 34(4): 14-22. doi: https://doi.org/10.3102/00131189X034004014.

Shams, F. (2019). Managing academic identity tensions in a Canadian public university: the role of identity work in coping with managerialism, Journal of Higher Education Policy and Management 41(6), 619-632. doi: https://doi.org/10.1080/1360080X.2019.1643960.

Sparkes, A. C. (2007). Embodiment, academics, and the audit culture: a story seeking consideration, Qualitative Research 7(4): 521-550. doi: https://doi.org/10.1177/146879 4107082306.

Statistics Sweden. (2012). Women and Men in Sweden: Facts and Figures 2012, Stockholm: Statistics Sweden. Available at: https://www.scb.se/contentassets/813b12534a254bb285 03983812d4649b/le0201 2012a01 br x10br1201eng.pdf.

Statistics Sweden. (2016). Universitetet och högskolor: Personal vid universitet och högskolor 2015 [Higher education: Employees in Higher Education 2015], Stockholm: Statistics Sweden.

Stensaker, B., Välimaa, J. \& Sarrico, C. S. (eds.) (2012). Managing Reforms in Universities. The Dynamics of Culture, Identity and Organizational Change, London: Palgrave MacMillan.

Stigmar, M. (2008). Faculty development through an educational action programme, Higher Education Research \& Development 27(2): 107-120. doi: https://doi.org/10.1080/07294 360701805242.

Thornton, M. (2013). The mirage of merit, Australian Feminist Studies 28(76): 127-143. doi: https://doi.org/10.1080/08164649.2013.789584.

Väänänen, A., Kevin, M. V., Ala-Mursala, L., Pentti, J., Kivimäki, M. \& Vahtera, J. (2004). The double burden of and negative spillover between pain and domestic work: associations with health among men and women, Women and Health 40(3): 1-18. 
Watermeyer, R. (2016). Public intellectuals vs. new public management: the defeat of public engagement in higher education, Studies in Higher Education 41(12): 2271-2285. doi: https://doi.org/10.1080/03075079.2015.1034261.

Weiler, K. (2008). The feminist imagination and educational research, Discourse: Studies in the Cultural Politics of Education 29(4): 499-507. doi: https://doi.org/10.1080/ 01596300802410219.

Whitchurch, C. (2008). Beyond administration and management: reconstructing the identities of professional staff in UK higher education, Journal of Higher Education Policy and Management 30(4): 375-386. doi: https://doi.org/10.1080/13600800802383042.

Wilson, J., Marks, G., Noone, L. \& Hamilton-MacKenzie, J. (2010). Retraining a foothold on the slippery paths of academia: university women, indirect discrimination, and the academic marketplace, Gender and Education 22(5): 535-545. doi: https://doi.org/10.1080/ $\underline{09540250903354404 .}$. 